\section{Wissen und Phänomen}

Afhandling forsvaret den 18. maj 1998 for den filosofiske doktorgrad ved Universitetet i Nice

Af seniorforsker Søren Gosvig Olesen

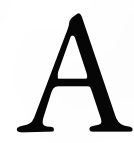

fhandlingen diskuterer Edmund Husserls, Alexandre Koyres og

Gaston Bachelards forfatterskaber med henblik paå forholdet mellem filosofien og videnskaberne.

Der fremlægges dels en sammenligning af de tre forfatterskaber, bragt i stand med begrebet ontologisk belysning som fællesnævner, dels en principiel overvejelse over filosofiens mulighed for at diskutere videnskab ud fra belysningen af den ontologiske ori- entering, som i forvejen ligger til grund for bestemte videnskaber. Afhandlingen er både komparativ og principiel, nemlig komparativ ved at forbinde traditioner, som normalt anses for adskilte, den tyske fænomenologiske og den franske epistemologiske, og principiel ved at skitsere en anden filosofisk tilgang til videnskaberne end den, man kender under betegnelsen videnskabsteori.

Omdrejningspunktet for afhandlingen, hvorved det komparative og det principielle forbindes, er begrebet historie. Dette begreb ses skærpet i Husserls forfatterskab hele vejen fra det tidlige skrift om talbegrebet til det sene fragment om geometriens oprindelse. I Koyres og Bachelards forfatterskaber bestemmes videnskabens virkelighed ud fra videnskabens historie, forestået som

Bedommelseskomiteen, fra venstre mod hojre, Pierre Livet, professor ved Université d'Aixen-Provence, Dominique Janicaud (formand), professor ved Université de Nice, Daniel Charles, professor ved Université de Nice (stedfortrader for Jean Grondin, professor ved Université de Montreal), Gérard Granel, professor ved Université de Toulouse, Jean-Paul Larthomas, professor ved Université de Nice. Foto: Susanne Hasman.

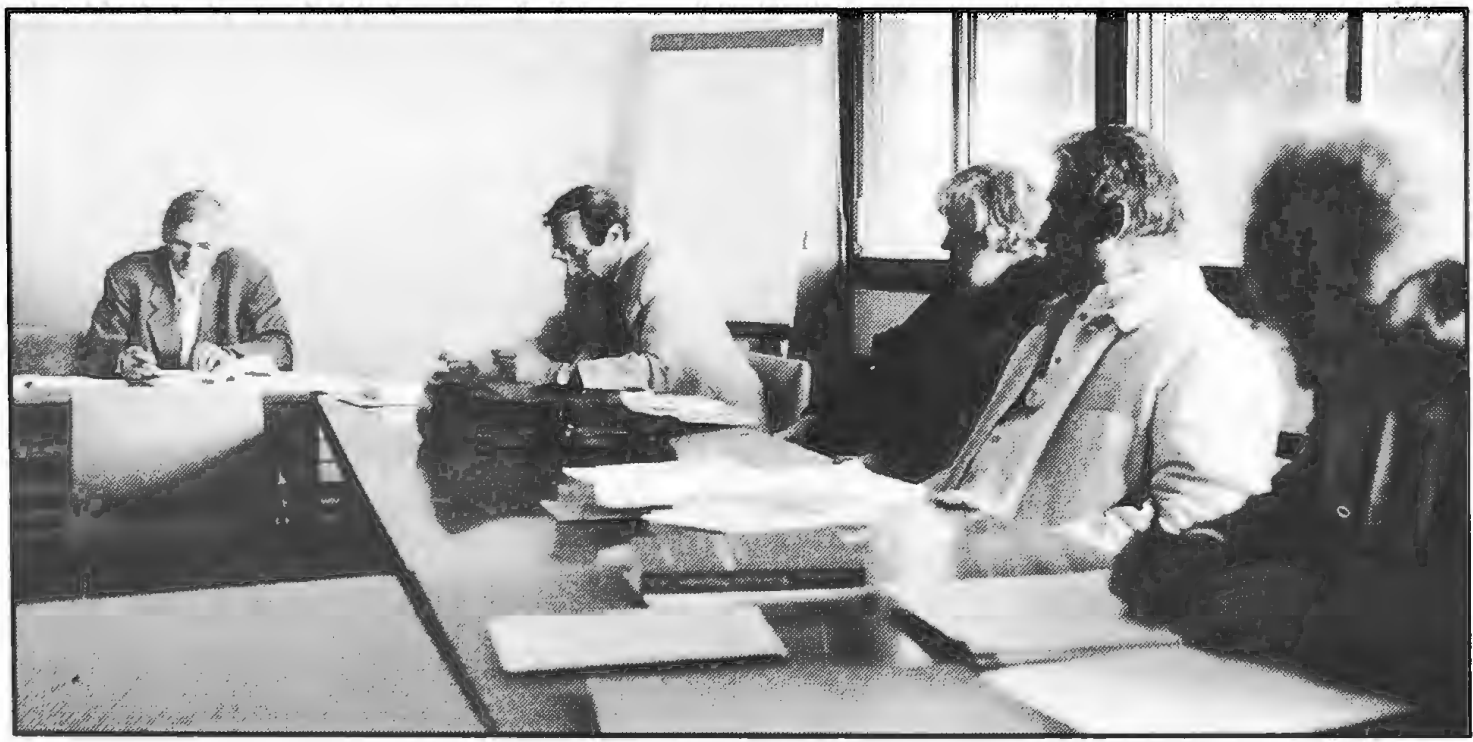




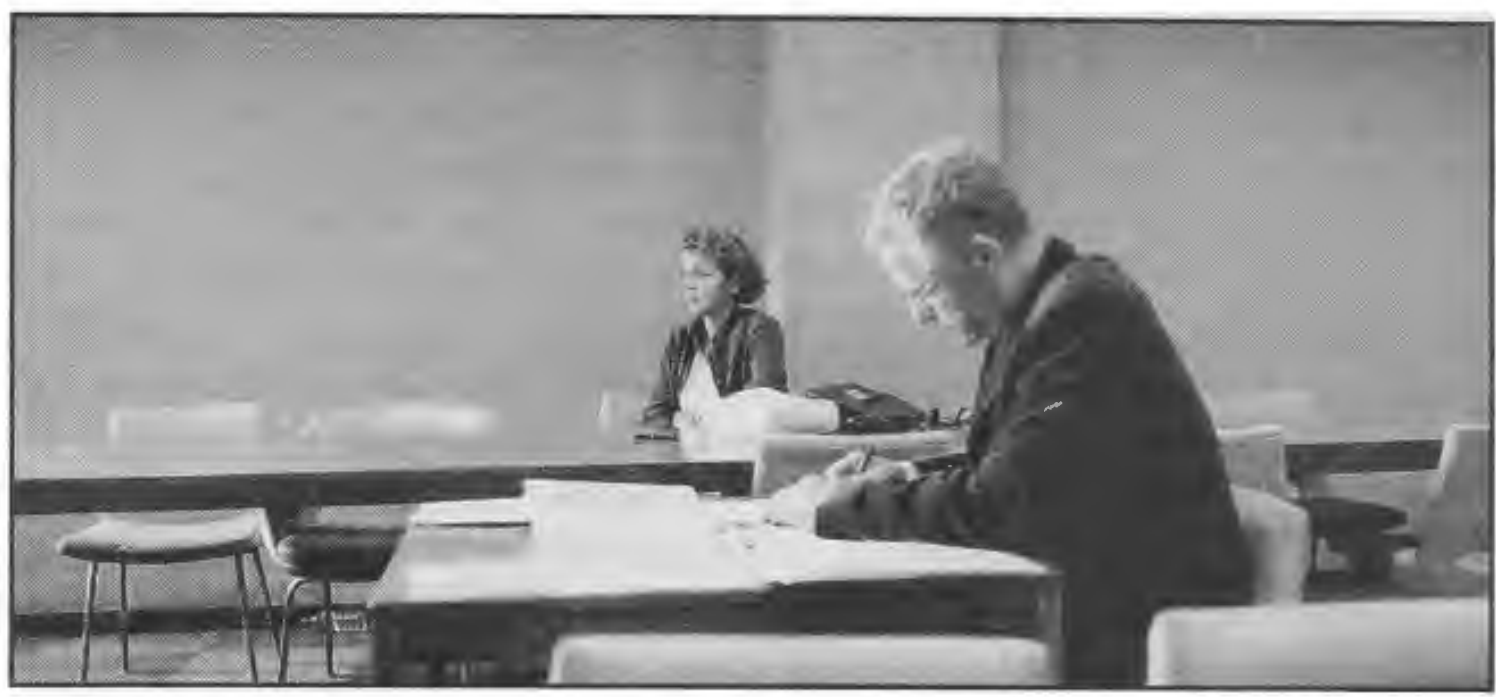

Doktoranden, Søren Gosvig Olesen, seniorforsker ved Det Kongelige Bibliotek. Foto: Susanne Hasman.

den sedimentering af teori, foreliggende i form af redskaber og læresætninger, som gør videnskaben mulig.

Videnskabsmandens anvendelse af videnskabens instrumenter beror på hans forståelse af deres mulighed. Kemiens tilblivelse som videnskab forsinkedes ikke af, at man ikke havde termometre, men af, at man ikke opfattede varme som noget eksakt måleligt - for at citere et eksempel, som optræder både hos Koyre og hos Bachelard. Omvendt kan videnskab degenerere til blot teknik, nar dens instrumenter alene forstås ud fra deres anvendelighed og ikke ud fra deres mulighed - en kritisk pointe, som er særligt fremherskende i Husserls forfatterskab.

Det er afhandlingens gennemgående tese, at den ontologiske belysning adskiller sig fra den metafysiske begrundelse af videnskaberne. Hvor metafysikken forudsætter en begrundende sidste instans, er det eneste absolutum forudsat af den ontologiske belysning overgangen fra før erkendelse til efter erkendelse. Denne overgang, hvorved fornuften kommer til sig selv og indtræder i sit lys, kan netop som overgang, bevægelse, ikke udgøre noget fast grundlag, men er dog absolut ved ikke at kunne reduceres bort fra nogen erkendelse. Denne bevægelses navn i filosofien er historie.

Wissen und Phänomen. Eine Untersuchung der ontologischen Klärung der Wissenschaften bei Edmund Husserl, Alexandre Koyré und Gaston Bachelard, 316 sider, udgivet pa forlaget Königshausen \& Neumann, Würzburg 1997. 